\title{
PENGARUH PENAMBAHAN BAUT DAN PAKU TERHADAP KUAT LENTUR BALOK LAMINASI KAYU MAHANG DAN MERANTI
}

\author{
Indriyani Puluhulawa', Alamsyah ${ }^{2}$, Diana Rafika ${ }^{3}$, Khoirunisak $^{4}$ \\ 1,2,3,4 Jurusan Teknik Sipil Politeknik Negeri Bengkalis \\ Email: indriyani_p@polbeng.ac.id
}

\begin{abstract}
The addition of bolts and nails as a shear connector on the laminate beam was expected to anticipate the problem on the laminate beam which only uses glue adhesive. The samples were a specimen of material properties and a specimen of the laminated beam, the dimension was $76 \times 5 \times 5 \mathrm{~cm}$ with three types of adhesive variation. The MOR value was obtained by one point load on the middle of the span. The value was the load and deflection, further calculated the value to get MOR and MOE. The MOR result of the addition of nail as the connector on the laminate beam by glue was increased $36.9 \%$. In contrast, the addition of bolt was decreased $49.86 \%$ compared to MOR BL LM. The addition of nails and bolts to laminated beams that used glue already showed the effect to decrease the MOE value of the laminate beam.
\end{abstract}

Keywords: Connector bolt and nail, Flexural strength, Laminate beam.

\begin{abstract}
ABSTRAK
Penambahan baut dan paku sebagai perekat diharapkan dapat mengantisipasi masalah yang umum terjadi pada balok laminasi yang hanya menggunakan perekat lem. Sampel yang dibuat meliputi sampel properties material serta sampel balok laminasi berukuran $76 \times 5 \times 5 \mathrm{~cm}$ sebanyak 3 tipe variasi jenis perekat. Nilai MOR diperoleh dengan pemberian beban satu titik ditengah bentang. Nilai yang diambil adalah beban dan lendutan, yang kemudian dihitung untuk mendapatkan nilai MOR dan MOE. Hasilnya penambahan paku sebagai penghubung/perekat pada balok laminasi yang menggunakan lem, dapat meningkatkan nilai MOR sebesar $36,9 \%$, sedangkan penambahan baut menyebabkan penurunan nilai MOR sebesar $49,86 \%$ dibandingkan terhadap nilai MOR BL LM. Penambahan paku dan baut pada balok laminasi yang menggunakan lem juga dapat menurunkan nilai MOE dari balok laminasi itu sendiri.
\end{abstract}

Kata kunci: Perekat baut dan paku, Kuat lentur, Balok laminasi.

\section{PENDAHULUAN}

Kayu meranti merupakan salah satu jenis kayu khas daerah tropis yang cukup terkenal. Kayu ini termasuk salah satu jenis kayu komersil yang banyak peminatnya. Dipasaran kayu meranti dikenal memiliki tiga jenis yang berbeda, yakni meranti merah, meranti putih, dan meranti kuning. kayu meranti merah tergolong kayu keras berbobot ringan sampai sedang. Berat jenisnya berkisar antara 0,3 - 0,86 pada kandungan air 15\%. Kayu terasnya berwarna merah muda pucat, merah muda kecoklatan, hingga merah tua atau bahkan merah tua kecoklatan. Menurut kekuatannya, jenis-jenis meranti merah dapat digolongkan dalam kelas kuat II-IV; sedangkan keawetannya tergolong dalam kelas III-IV.

Kayu mahang merupakan jenis kayu yang relatif ringan dan memiliki tingkat keawatan yang agak rendah. Kayu ini umumnya memiliki densitas yang berkisar antara 270$500 \mathrm{~kg} / \mathrm{m}^{3}$ pada kadar air 15\%. Memiliki batang bulat, halus, dan berwarna agak abu-abu kehijauan. Diameter batang dapat mencapai $70 \mathrm{~cm}$ dan kadang-kadang berbanir tetapi kecil. kayunya ringan dengan berat jenis (BJ) 0,45. Kelas keawetan $\mathrm{V}$ dan kelas kekuatan III. 
Balok laminasi adalah salah satu produk rekayasa yang diciptakan untuk meningkatkan kualitas kayu struktural serta menjawab kebutuhan akan dimensi dan panjang bentang kayu struktural. Dalam pembuatan balok laminasi penyusunan setiap lamina dengan perekat dapat diatur sedemikian rupa sehingga bisa meningkatkan sifat-sifat kekuatan kayu yang digunakan.

Laminasi kayu meranti dengan kayu mahang pada dasarnya merupakan upaya untuk meningkatkan efesiensi penggunaan bahan baku kayu meranti sebagai kayu keras dan meningkatkan mutu dari kayu mahang sebagai kayu ringan sehingga dapat digunakan untuk kayu struktural.

Keberhasilan proses laminasi dipengaruhi oleh beberapa aspek antara lain : aspek bahan yang direkat, aspek bahan perekat dan aspek teknologi perekatan. Kesesuaian antara perekat, sifat bahan dan teknik perekatan sebagai landasan untuk keberhasilan dan kualitas produk laminasi. Kekuatan rekatan dapat dijadikan sebagai tolak ukur keberhasilan produksi laminasi.

Laminasi pada umumnya menggunakan perekat lem sebagai penghubung antar setiap lamina, namun masalah yang sering timbul adalah perekat lem kadang-kadang tidak bisa merekat dengan sempurna pada setiap lamina sehingga proses laminasi tidak terjadi.

Kajian penambahan baut dan paku sebagai bahan perekat pada balok laminasi kayu meranti dan kayu mahang pada dasarnya merupakan upaya untuk mengantisipasi masalah yang timbul pada balok laminasi jika hanya menggunakan perekat lem, sehingga proses laminasi dapat terjadi dengan sempurna dan peningkatan sifat mekanik seperti kuat lentur dan modulus elastisitas bisa tercapai serta dapat menjadi pertimbangan untuk merekomendasikan penggunaan balok laminasi kayu meranti dan kayu mahang sebagai bahan baku alternatif yang ditinjau dari aspek teknologi dan ekonomi.

Kekuatan lentur atau sering dikenal dengan istilah Modulus of Rupture (MOR) menentukan kapasitas beban eksternal yang mampu dipikul oleh sebuah balok.

lensufrie (2009: 14) menyatakan, kelenturan kayu adalah kemampuaan kayu untuk melengkungkan diri ketika menahan tekanan diatasnya. Menurut Dumanauw (1984: 24) menyebutkan, keteguhan lengkung atau lentur ialah kekuatan untuk menahan gaya - gaya yang berusaha melengkungkan kayu atau untuk menahan beban - beban mati maupun hidup selain beban pukulan yang harus dipikul oleh kayu tersebut, misalnya blandar. Nilai ini dihitung dengan menggunakan persamaan (2), berikut:

$$
M O R=\frac{3 . P . L}{2 \cdot b \cdot h^{2}}
$$

Pers. 1

\section{Dimana:}

$\mathrm{P}$ adalah beban $(\mathrm{kg}), \mathrm{L}$ adalah panjang bentang pengujian balok $(\mathrm{cm}), \Delta$ adalah defleksi $(\mathrm{cm}), b$ adalah lebar $(\mathrm{cm})$, serta $h$ adalah tinggi balok (cm).

Modulus elastisitas merupakan ukuran terhadap perpanjangan bila balok kayu mengalami tarikan, pemendekan apabila balok kayu mengalami tekakan selama pembebanan berlangsung dengan kecepatan pembebanan konstan.

Modulus Elastisitas (MOE) menggambarkan ketahanan terhadap lentur, yang berhubungan langsung dengan kekakuan (Akhtari et al. 2012). Nilai ini dihitung dengan menggunakan 
persamaan (2), dimana: $\mathrm{P}$ : beban $(\mathrm{kg}), \mathrm{L}$ : panjang bentang pengujian balok $(\mathrm{cm}), \Delta$ : defleksi $(\mathrm{cm}), \mathrm{b}$ : lebar $(\mathrm{cm}), \mathrm{h}:$ tinggi $(\mathrm{cm})$.

$M O E=\frac{P L^{3}}{4 \Delta b h^{3}} \quad$ …...... Pers.2

Dalam Kajian ini digunakan acuan Tata Cara Perencanaan Konstruksi Kayu (SNI kayu) untuk mengetahui kekuatan mekanik. Berikut tabel kuat acuan berdasarkan atas pemilahan secara mekanik menurut SNI 7973-2013. Untuk pengklasifikasian balok laminasi berdaun lebar dapat dilihat pada Tabel 5B dan untuk pengklasifikasian balok solid dapat dilihat pada Tabel 4.2.1 pada SNI 7973-2013.

Pemilahan secara visual harus mengikuti standar pemilahan secara visual yang baku. Nilai kuat acuan mekanik kayu dapat dilihat pada Tabel 2.2 berdasarkan pada nilai modulus elastisitas lentur acuan (Ew). Untuk hasil pengujian dilaboratorium nilai kuat acuan dapat dihitung menggunakan Pers. 3 :

$F=\frac{F_{A v g}-(1,645 . S T D)}{\gamma_{D L}} \gamma_{K A}$ Pers.3

Dengan :

$F_{\text {Avg }}$ : nilai rata-rata

STD : nilai standar deviasi

$\gamma_{D L} \quad:$ faktor lama pembebanan

$\gamma_{K A}$ : faktor koreksi kadar air

Faktor koreksi lama pembebanan $\left(\mathrm{V}_{\mathrm{DL}}\right)$ memperhitungkan time-dependent behavior kayu. Kayu memberi kekuatan tinggi untuk pembebanan dalam waktu singkat dan begitu pula sebaliknya. Faktor koreksi ini bernilai 1,0 untuk pembebanan dengan durasi 10 tahun. Sedangkan untuk pengujian di laboratorium dengan lama pembebanan sekitar 3 sampai 5 menit faktor koreksi bernilai 1,65. Faktor koreksi kadar air dianggap bernilai sama dengan 1,0 jika nilai kadar air rata-rata hasil pengujian berkisar antara $12 \%$ hingga 15\%. (Awaludin Ali, 2011)
Blass dkk, 1995 dalam Budi A.S, 2007 struktur laminasi memiliki beberapa kelebihan dibanding dengan kayu yang solid. Yakni ukuran dapat dibuat lebih tinggi dan lebih lebar, bentangan lebih panjang dan konfigurasi bentuk difabrikasi dengan mudah. Karakteristik penting balok laminasi menghasilkan kekuatan yang melebihi dibandingkan lapisan tunggal serta deformasi yang terjadi lebih kecil.

Prayitno, 1996 dalam Budi A.S, 2007, proses laminasi dan penyambungan sangat terkait dengan proses perekatan. Dalam proses perekatan bambu ada tiga aspek utama yang mempengaruhi kualitas hasil perekatan, yaitu aspek bahan yang direkat, aspek bahan perekat dan aspek teknologi perekatan. Aspek bahanyang direkat (bambu) meliputi struktur anatomi bambu (susunan sel, arah serat) dan sifat fisika (kerapatan, kadar air, kembang susut dan porositas). Aspek teknologi perekatan meliputi komposisi perekat, berat laburan, pengempaan dan kondisi kerja..(Pdersars?) suhu, cara pelaksanaan).

Untuk tujuan meningkatkan mutu kayu Mahang pada pembuatan balok laminasi dipakai penampang berdasarkan konsep tegangan balok terlentur seperti Gambar 1 berikut ini.

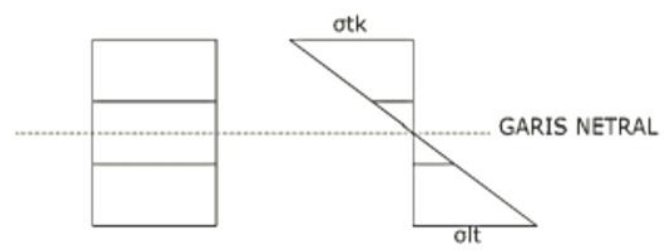

Gambar 1. Diagram tegangan lentur balok

Pada bagian atas dari diagram menunjukkan serat terluar mengalami tegangan tekan maksimum akibat diberi beban lentur pada balok laminasi, sebaliknya pada bagian bawah mengalami tegangan tarik maksimum, sedangkan 
pada bagian tengah (garis netral) tidak mengalami tegangan tekan maupun tarik, jadi semakin mendekati garis netral tegangan semakin kecil. Oleh karena itu pada bagian tersebut tidak perlu menggunakan jenis kayu yang memiliki kekuatan atau mutu yang tinggi, dengan kata lain kayu yang bermutu tinggi ditempatkan pada bagian sisi terluar balok laminasi.

Handayani (2009) dalam Pramudito J (2013) lem epoksi merupakan produk sinetik termoset dari resin poloeposi dengan zat curing/pengeras (asam/basa). Lem epoksi dapat diperoleh dalam bentuk sistem satu atau dua komponen. Sistem satu komponen meliputi resin cair bebas pelarut, larutan, pasta resin, cair, bubuk, pallet dan pasta. Sistem dua komponen terdiri dari resin dan zat curing yang dicampur pada saat akan digunakan, setelah dicampur sebaiknya segera digunakan untuk mengelem.

Handayani (2009) dalam Jihannanda $P$ (2013) lem epoksi juga memiliki kelebihan dan kelemahan, kelebihannya antara lain tidak berubah walaupun telah bertahuntahun disimpan, tahan terhadap minyak, gemuk, bahan bakar minyak, alkali, pelarut aromat, asam, alkohol, juga panas dan cuaca dingin. Sedangkan kekurangannya adalah lemah terhadap keton dan ester, ada juga yang formulasinya tidak tahan terhadap minyak, apabila campuran lem epoksi tercelup air dalam jangka waktu yang lama maka lem epoksi akan rusak, pada sistem polomina dan pada sistem polomina dan anhidrida tidak tahan pada suhu dingin/beku.

Kayu Mahang mempunyai berat jenis minimum 0,33 dan maksimum 0,55 kelas awet IV-V dan kelas kuat II-IV. Kayu Mahang termasuk kayu lunak dan kekerasan ringan sampai sedang, pada umumnya spesies ini kerapatan berkisar dari $270-495 \mathrm{~kg} / \mathrm{m} 3$ kering udara, seratnya lurus atau agak berpilin, teksturnya agak halus hingga agak kasar, merata. Kayu ini memiliki sifat kembang-susut yang tergolong sedang, dan dalam proses pengeringan, kayu mahang tergolong kurang awet.

Meranti merah tergolong kayu keras berbobot ringan sampai berat-sedang. Berat jenisnya berkisar antara 0,3-0,86 pada kandungan air $15 \%$. Kayu terasnya berwarna merah muda pucat, merah muda kecoklatan, hingga merah tua atau bahkan merah tua kecoklatan. keawetannya tergolong dalam kelas III-IV. Kayu ini tidak begitu tahan terhadap pengaruh cuaca, sehingga tidak dianjurkan untuk penggunaan di luar ruangan dan yang bersentuhan dengan tanah. Namun kayu meranti merah cukup mudah diawetkan dengan menggunakan campuran minyak diesel dengan kreosot.

\section{METODE}

Kajian ini dilakukan di Laboratorium Uji Bahan Program Studi Teknik Sipil dan Laboraturim Uji Bahan Program Studi Teknik Mesin Politeknik Negeri Bengkalis, waktu Kajian dilakukan selama 3 bulan, yaitu bulan Juni s/d Agustus 2017.

Bahan utama yang digunakan adalah kayu Mahang dan kayu Meranti yang diperoleh dari pedagang kayu yang ada di pulau Bengkalis Prov. Riau. Untuk bahan perekat yang digunakan ada 3 jenis diantaranya lem epoxy Merk Qbond yang terdiri dari resin dan hardener, kemudian baut diameter $12 \mathrm{~mm}$ panjang $6 \mathrm{~cm}$ serta paku 2 inch. 
Pengujian properties material seperti kuat tekan dan kuat geser menggunakan alat mesin uji tekan Merk ELE dengan kapasitas $1500 \mathrm{KN}$, kemudian untuk pengujian tarik kayu menggunakan UTM. Serta untuk pengujian lentur balok laminasi menggunakan alat Flexure strengt test.

Benda uji yang dibuat terdiri dari benda uji untuk pengujian properties material serta benda uji balok laminasi kayu Mahang dan Meranti dengan jumlah setiap jenis berbeda-beda. Untuk pengujian properties antara 10-15 sampel, sementara untuk balok laminasi hanya 5 sampel tiap variasinya. Variasi balok laminasi yang dibuat diantaranya balok laminasi perekat lem, balok laminasi perekat paku jarak 5 $\mathrm{cm}$, balok laminasi perekat baut jarak $5 \mathrm{~cm}$, balok laminasi perekat lem + paku dengan jarak $5 \mathrm{~cm}$ dan balok laminasi perekat lem + baut dengan jarak $5 \mathrm{~cm}$. Detail jumlah benda uji dapat dilihat pada Tabel berikut.

Tabel 1 Detail benda uji

\begin{tabular}{clcc}
\hline No & \multicolumn{1}{c}{ Nama Sampel } & $\begin{array}{c}\text { Jumlah } \\
\text { Sampel }\end{array}$ & $\begin{array}{c}\text { Jarak } \\
\text { perekat }\end{array}$ \\
\hline 1 & $\begin{array}{l}\text { Balok Laminasi perekat } \\
\text { lem (BL LM) }\end{array}$ & 5 & \\
\hline 2 & $\begin{array}{l}\text { Balok Laminasi perekat } \\
\text { lem + paku (BL LP) }\end{array}$ & 5 & $5 \mathrm{~cm}$ \\
\hline 3 & $\begin{array}{l}\text { Balok Laminasi perekat } \\
\text { lem + Baut (BL LB) }\end{array}$ & 5 & $5 \mathrm{~cm}$ \\
\hline
\end{tabular}

Balok laminasi dibuat 5 layer dengan tebal setiap layer $1 \mathrm{~cm}$ dan panjang $76 \mathrm{~cm}$ serta lebar $5 \mathrm{~cm}$. kayu Meranti ditempatkan pada layer pertama dan kelima, hal ini dilakukan mengingat mutu kayu Meranti lebih kuat dibandingan dengan kayu Mahang, sehingga kayu Meranti dapat bekerja maksimal untuk memikul tarik pada bagian bawah balok dan tekan pada bagian atas balok. Dan untuk 3 layer bagian tengah diisi dengan kayu Mahang.

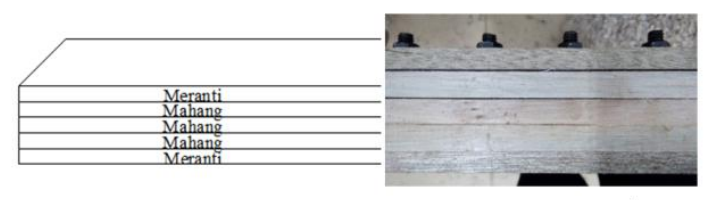

Gambar 2. Layer/lamina pada balok laminasi

Proses perekatan pada balok laminasi yang menggunakan perekat lem, perekat diaplikasikan pada salah satu permukaan layer yang akan direkatkan kemudian di klem/dijepit selama kurang lebih 4 jam sesuai dengan petunjuk pemakaian pada produk lemnya. Sementara untuk balok laminasi yang tidak menggunakan perekat lem epoxy, setelah disusun maka proses selanjutnya membuat lubang untuk baut dengan cara dibor menggunakan mata bor yang ukurannya lebih kecil dari diameter baut, dan untuk yang menggunakan paku, di paku selang-seling dari arah atas dan bawah balok untuk balok laminasi yang menggunakan paku.

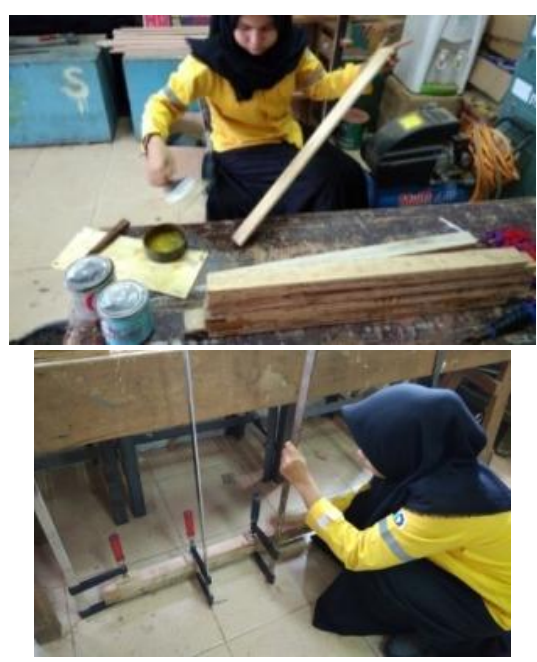

Gambar 3a. Proses pemasangan bahan perekat 


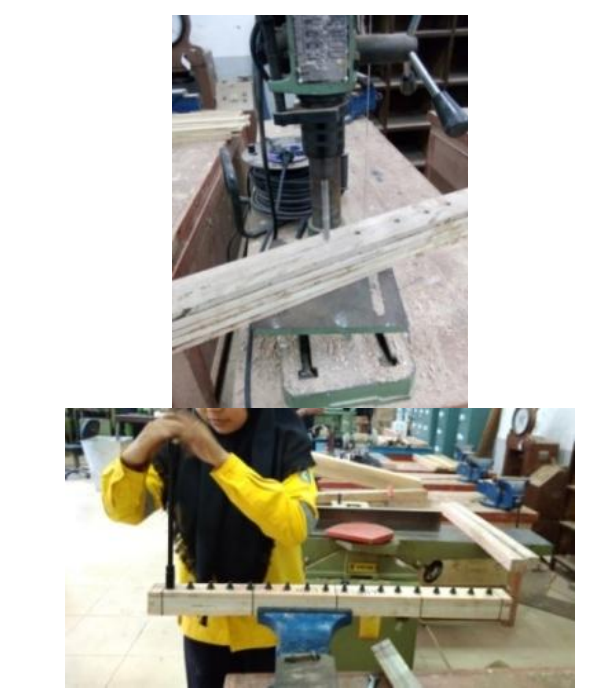

Gambar 3b. Proses pemasangan bahan perekat

Pengujian yang dilakukan meliputi pengujian properties material kayu Mahang dan kayu Meranti serta pengujian lentur untuk balok laminasi. Untuk pengujian properties material diantaranya: pengujian kadar air, pengujian berat jenis kayu, pengujian kuat tekan sejajar serat, pengujian kuat tekan tegak lurus serat, pengujian kuat geser, pengujian kuat tarik yang berdasarkan pada aturan yang berlaku. Untuk pengujian lentur balok laminasi, dilakukan dengan mengacu pada SNI 03-3959-1995. Dimana jarak antara tumpuan balok $71 \mathrm{~cm}$ dengan beban 1 titik pada tengah bentang.

Guna menentukkan besarnya nilai modulus elatisitas balok laminasi, pada saat pengujian lentur, diukur juga lendutan yang terjadi pada tengah bentang dan seperempat bentang.

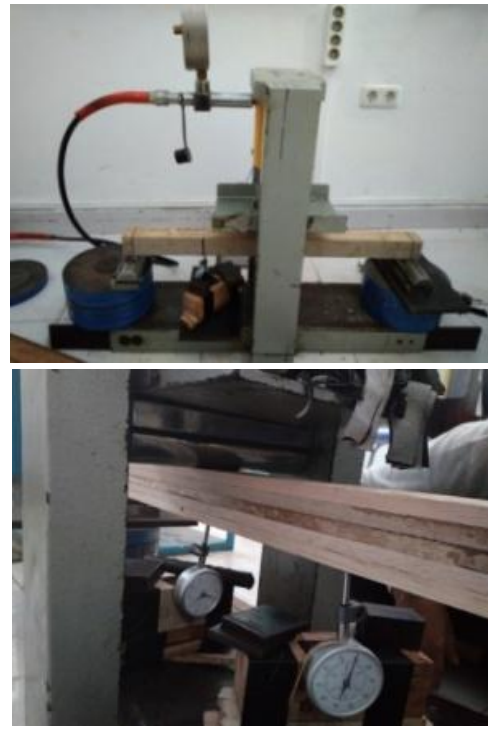

Gambar 4. Pengujian lentur balok

\section{HASIL DAN PEMBAHASAN}

Dari hasil pengujian yang dilakukan diperoleh nilai kadar air rata-rata kayu Mahang diperoleh sebesar 14,05\% dan berat jenis kayu Mahang 0,36. Kadar air kayu Meranti sebesar $14,67 \%$ dan berat jenis kayu Meranti sebesar 0,43.

Hasil pengujian kuat tekan sejajar serat, kuat tekan tegak lurus serat, kuat geser, kuat tarik dan kuat lentur serta nilai MOE dari kayu Mahang dan kayu Meranti Merah, dapat dilihat pada Tabel 2 berikut ini.

Gambar-gambar hasil pengujian properties material kayu Mahang dan kayu Meranti dapat dilihat pada Gambar

Tabel 2. Hasil pengujian properties material kayu Mahang dan kayu Meranti

\begin{tabular}{lcccccc}
\hline \multirow{2}{*}{ Jenis pengujian } & \multicolumn{3}{c}{ Kayu Mahang } & \multicolumn{3}{c}{ Kayu Meranti Merah } \\
\cline { 2 - 7 } & $\begin{array}{c}\text { Rata-rata } \\
\text { (Mpa) }\end{array}$ & $\begin{array}{c}\text { standar } \\
\text { Deviasi }\end{array}$ & $\begin{array}{c}\text { Kuat } \\
\text { acuan } \\
\text { (Mpa) }\end{array}$ & $\begin{array}{c}\text { Rata-rata } \\
\text { (Mpa) }\end{array}$ & $\begin{array}{c}\text { standar } \\
\text { Deviasi }\end{array}$ & $\begin{array}{c}\text { Kuat } \\
\text { acuan } \\
\text { (Mpa) }\end{array}$ \\
\hline Kuat tekan sejajar serat & 26,77 & 1,57 & 14,66 & 27,04 & 2,19 & 14,20 \\
\hline $\begin{array}{l}\text { Kuat tekan tegak lurus } \\
\text { serat }\end{array}$ & 8,20 & 1,37 & 3,60 & 15,72 & 2,94 & 6,59 \\
\hline
\end{tabular}


Pengaruh Penambahan Baut ... (Indriyani/ hal. 62-74)

\begin{tabular}{lcccccc}
\hline & \multicolumn{3}{c}{ Kayu Mahang } & \multicolumn{3}{c}{ Kayu Meranti Merah } \\
\cline { 2 - 7 } Jenis pengujian & $\begin{array}{c}\text { Rata-rata } \\
\text { (Mpa) }\end{array}$ & $\begin{array}{c}\text { standar } \\
\text { Deviasi }\end{array}$ & $\begin{array}{c}\text { Kuat } \\
\text { acuan } \\
\text { (Mpa) }\end{array}$ & $\begin{array}{c}\text { Rata-rata } \\
\text { (Mpa) }\end{array}$ & $\begin{array}{c}\text { standar } \\
\text { Deviasi }\end{array}$ & $\begin{array}{c}\text { Kuat } \\
\text { acuan } \\
\text { (Mpa) }\end{array}$ \\
\hline Kuat Geser & 8,61 & 2,57 & 2,66 & 6,23 & 0,72 & 3,06 \\
\hline Kuat Tarik & 70,50 & 13,67 & 29,10 & 120,49 & 15,04 & 58,03 \\
\hline Kuat Lentur & 48,47 & 3,46 & 25,93 & 70,64 & 3,31 & 39,52 \\
\hline MOE & & 5013,89 & & & 7438,14 & \\
\hline
\end{tabular}

Dari Tabel 2 diketahui nilai kuat tekan // serat, kuat tekan $\perp$ serat, kuat geser, kuat tarik, dan kuat lentur material kayu Meranti Merah lebih besar dibandingkan dengan kayu Mahang, atau kayu Meranti masuk dalam grade E7 dan kayu Mahang grade E5 berdasarkan klasifikasi pada Tabel 4.2.1 SNI 7973 2013. Hal ini sesuai dengan prediksi penulis karena kayu Mahang merupakan kayu ringan dengan umur tumbuh yang cepat, sehingga banyak dimanfaatkan bukan untuk kayu struktural.

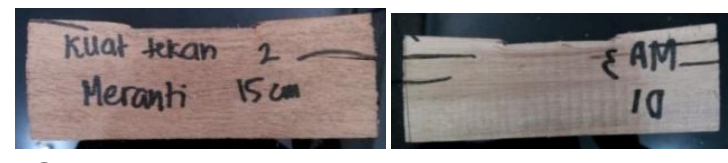

Gambar 5. Hasil Pengujian kuat tekan sejajar serat dan tegak lurus serat

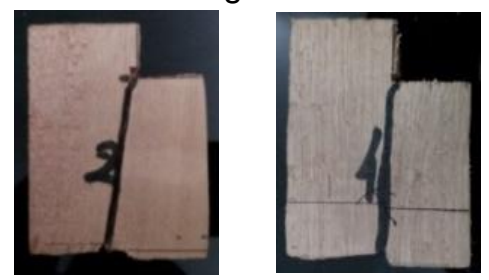

Gambar 6. Hasil Pengujian Geser

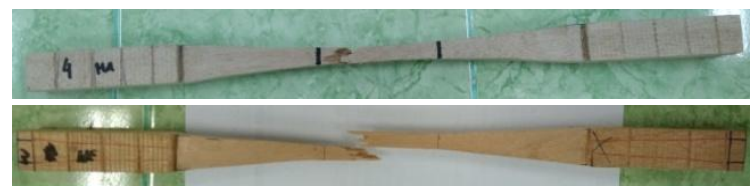

Gambar 7. Hasil Pengujian kuat tarik kayu
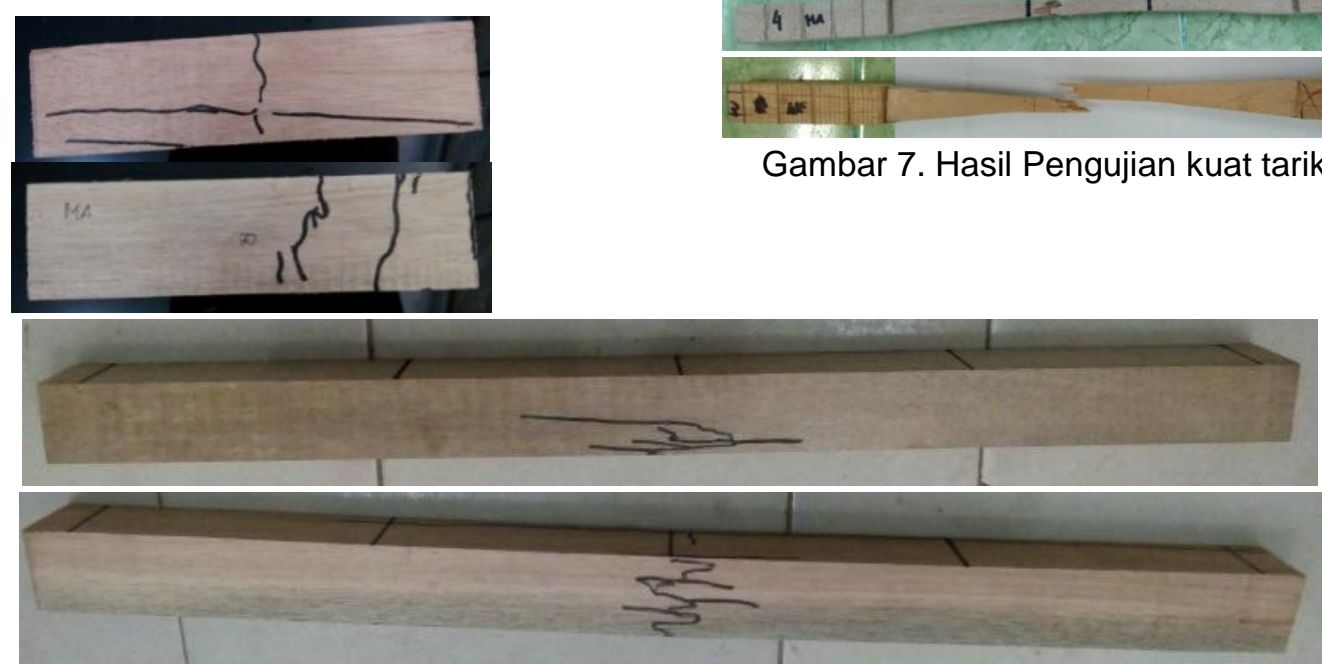

Gambar 8. Hasil pengujian luat lentur kayu

Pada pengujian lentur balok laminasi dilakukan pencatatan beban pada saat lendutan izin terjadi dan pencatatan lendutan pada saat beban maksimum terjadi. Besarnya beban izin rata-rata yang terjadi pada saat lendutan izin dan beban maksimum rata-rata dapat dilihat pada Tabel 3 berikut. Untuk detail beban dan lentutan yang terjadi dapat dilihat pada Gambar.

Tabel 3. Beban lentur rata-rata dan lendutan rata-rata balok laminasi

\begin{tabular}{ccccc}
\hline $\begin{array}{c}\text { Nama } \\
\text { Sample }\end{array}$ & $\begin{array}{c}\Delta \mathbf{i} \\
(\mathbf{m m})\end{array}$ & $\begin{array}{c}\mathbf{P i} \\
\mathbf{( k N )}\end{array}$ & $\begin{array}{c}\Delta \mathbf{u} \\
(\mathbf{m m})\end{array}$ & $\begin{array}{c}\mathbf{P u} \\
(\mathbf{k N})\end{array}$ \\
\hline BL LM & 2,37 & 2,14 & 16,91 & 8,31 \\
\hline BL LP & 2,37 & 1,58 & 28,16 & 10,27 \\
\hline
\end{tabular}




\begin{tabular}{ccccc}
\hline $\begin{array}{c}\text { Nama } \\
\text { Sample }\end{array}$ & $\begin{array}{c}\Delta \mathbf{i} \\
(\mathbf{m m})\end{array}$ & $\begin{array}{c}\mathbf{P i} \\
(\mathbf{k N})\end{array}$ & $\begin{array}{c}\Delta \mathbf{u} \\
(\mathbf{m m})\end{array}$ & $\begin{array}{c}\mathbf{P u} \\
(\mathbf{k N})\end{array}$ \\
\hline BL LB & 2,37 & 0,60 & 13,98 & 4,07 \\
\hline
\end{tabular}

Pada batas lendutan ijin 2,37 $\mathrm{mm}$, besarnya beban lentur berbeda-beda untuk 3 variasi balok laminasi. Balok yang menggunakan perekat lem (BL LM) memperoleh beban lentur rata-rata sebesar 2,14 kN dan pada saat beban maksimum tercapai besarnya lendutan rata-rata BL LM adalah $16,91 \mathrm{~mm}$ atau 7 kali lebih besar dari lendutan izin.

Balok laminasi yang menggunakan perekat lem + paku, pada saat lendutan izin tercapai, nilai beban lentur rata-ratanya adalah sebesar 1,58 $\mathrm{kN}$ dan pada saat beban maksimum tercapai nilai lendutan rata-rata $\mathrm{BL} \mathrm{LP}$ adalah $28,16 \mathrm{~mm}$ atau mencapai 12 kali lebih besar dibandingkan dengan lendutan izinnya.

Pada balok laminasi yang menggunakan perekat lem + baut, saat lendutan izin tercapai nilai beban lentur yang diperoleh yaitu sebesar 0,6 kN dan pada saat beban maksimum tercapai lendutan maksimumnya sebesar $13,98 \mathrm{~mm}$ atau 6 kali lebih besar dibanding lendutan izinnya.

Hubungan antara beban izin dan beban lentur dari 3 jenis balok laminasi dapat dilihat pada Gambar 9. Serta hubungan antara beban versus lendutan dari 3 variasi balok laminasi dapat di lihat pada Gambar 10 sampai Gambar 12.

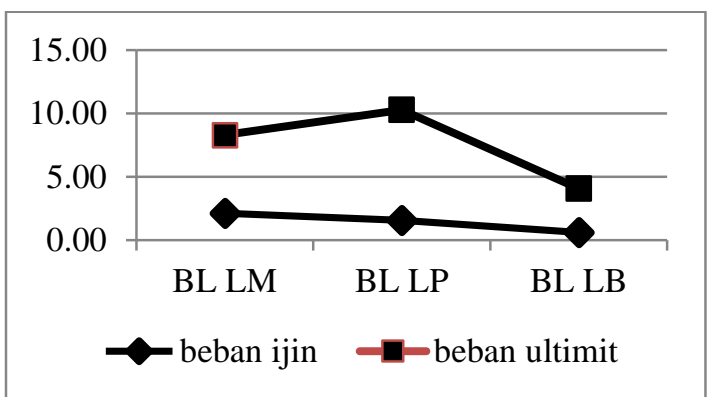

Gambar 9. Beban lentur dan lendutan BL LM dan balok laminasi dengan dua bahan perekat

Balok yang menggunakan perekat lem (BL LM) mempunyai beban lentur izin rata-rata yang lebih besar jika dibandingan dengan balok yang menggunakan dua bahan perekat yaitu sebesar 2,14 kN, 1,58 kN untuk BL LP dan 0,6 kN untuk BL LB. Hal ini menunjukkan bahwa pada saat lendutan izin penambahan paku dan baut menyebabkan penurunan kapasitas lentur balok laminasi.

Dari tiga jenis variasi balok laminasi yang mempunyai beban lentur rata-rata terbesar yaitu BL LP dengan nilai $10,27 \mathrm{kN}$, tetapi dibarengi pula dengan lendutan yang terbesar yaitu 28,16 $\mathrm{mm}$. hal ini menunjukkan bahwa pada kondisi ultimit penambahan perekat paku pada balok laminasi menyebabkan peningkatan kapasitas lentur. 
Pengaruh Penambahan Baut ... (Indriyani/ hal. 62-74)

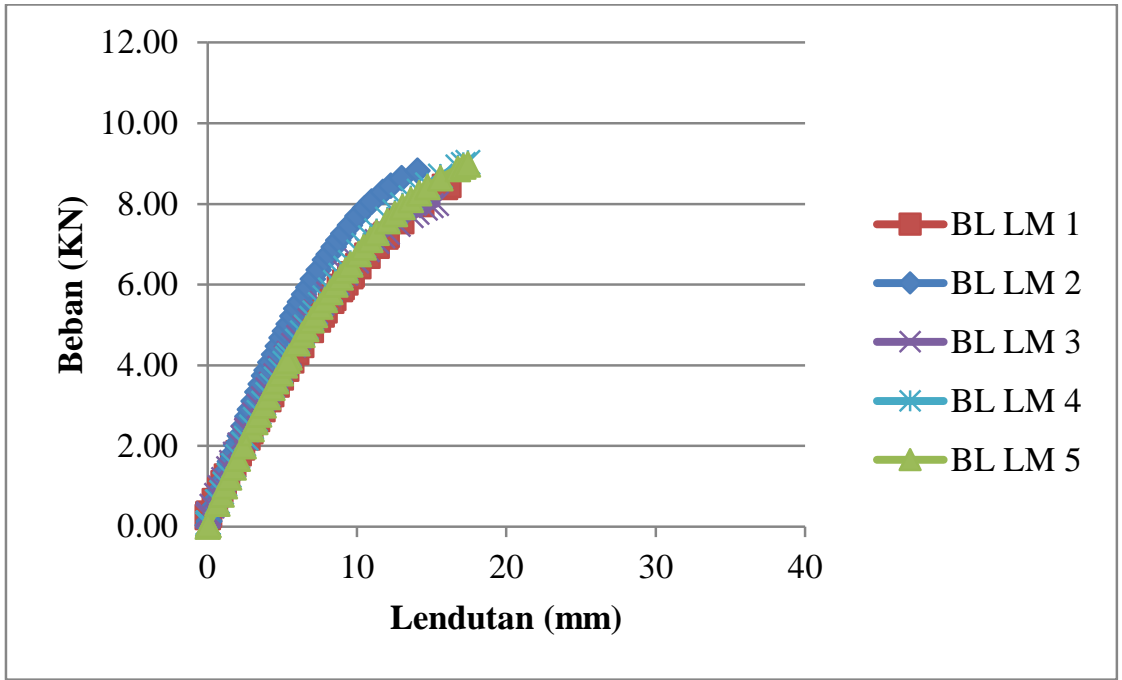

Gambar 10. Grafik hubungan beban versus lendutan balok laminasi dengan perekat lem (BL LM)

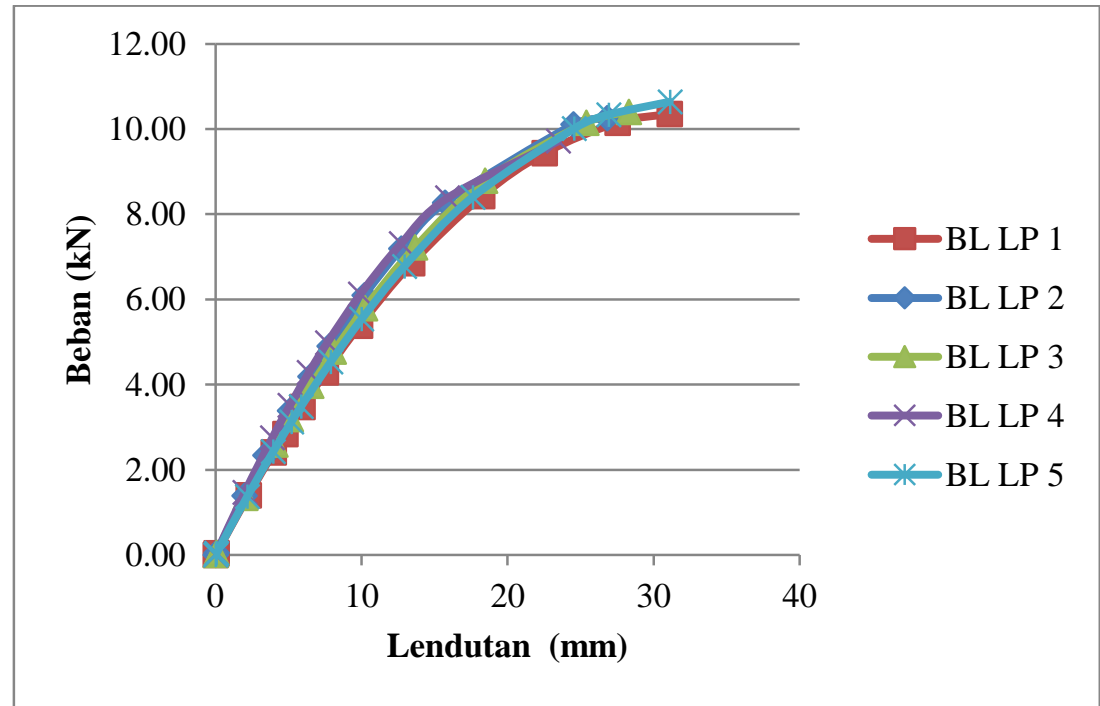

Gambar 11. Grafik hubungan beban versus lendutan balok laminasi dengan perekat lem+paku (BL LP)

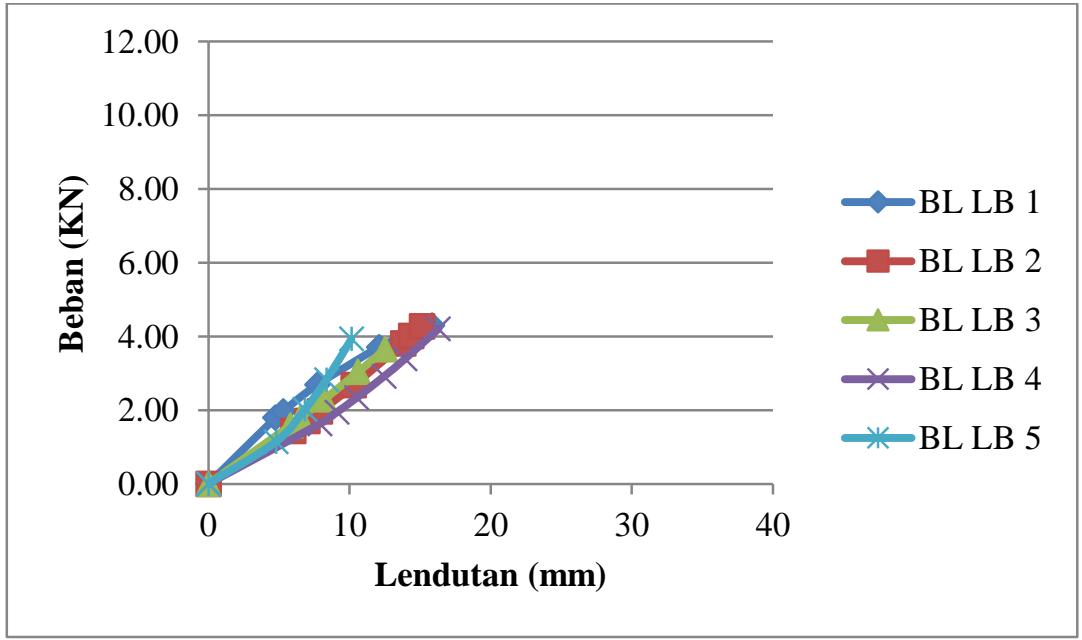

Gambar 12. Grafik hubungan beban versus lendutan balok laminasi dengan perekat lem+baut (BL LB) 
Dari Gambar 10 sampai Gambar 12 terlihat perbedaan yang jelas dari ketiga jenis balok laminasi, pada skala sumbu yang sama, Gambar 10 atau balok laminasi BL LM menunjukkan grafik yang lebih tegak dibandingkan dengan grafik balok laminasi yang lain. Hal ini menunjukkan bahwa $B L$ LM punya kekakuan yang lebih besar dibandingan balok laminasi yang lain.
Penentuan besarnya nilai MOR dari balok laminasi dilakukan dengan menggunakan Persamaan 1 dengan mengacu pada SNI 03-3959-1995, dan besarnya nilai MOR acuan di tentukan menggunakan Persamaan 3. Hasilnya kemudian dibandingkan terhadap nilai MOR balok Solid kayu Mahang (MA) dan balok solid kayu Meranti Merah (ME) serta balok laminasi dengan lem (BL LM), seperti pada Tabel 2 berikut ini.

Tabel 4. Perbandingan nilai MOR balok laminasi

\begin{tabular}{cccccccc}
\hline No & $\begin{array}{c}\text { Nama } \\
\text { Sample }\end{array}$ & $\begin{array}{c}\text { MOR } \\
\text { Rata- } \\
\text { rata } \\
\text { (Mpa) }\end{array}$ & $\begin{array}{c}\text { Standar } \\
\text { deviasi }\end{array}$ & $\begin{array}{c}\text { MOR } \\
\text { Acuan } \\
\text { (Mpa) }\end{array}$ & $\begin{array}{c}\text { Perbandingan } \\
\text { terhadap MA } \\
(\%)\end{array}$ & $\begin{array}{c}\text { Perbandingan } \\
\text { terhadap ME } \\
(\%)\end{array}$ & $\begin{array}{c}\text { Perbandingan } \\
\text { terhadap BL } \\
\text { LM (\%) }\end{array}$ \\
\hline 1 & BL LM & 69,47 & 5,49 & 36,63 & 41,26 & $-7,31$ & 0,00 \\
\hline 2 & BL LP & 86,94 & 2,55 & 50,15 & 93,38 & 26,89 & 36,90 \\
\hline 3 & BL LB & 34,10 & 2,31 & 18,37 & $-29,18$ & $-53,53$ & $-49,86$ \\
\hline
\end{tabular}

Dari Tabel 4 diketahui bahwa Untuk balok laminasi yang menggunakan lem (BL LM) nilai mempunyai nilai MOR acuan sebesar 36,63 Mpa, atau lebih besar 41,26\% jika dibandingkan dengan balok solid kayu Mahang, tetapi lebih kecil 7,31\% jika dibandingkan dengan balok solid kayu Meranti Merah.

Balok laminasi yang menggunakan 2 bahan perekat, seperti balok BL LP, mempunyai nilai MOR sebesar 50,15 Mpa atau meningkat 93,38\% jika dibandingkan terhadap nilai MOR balok kayu Mahang, meningkat $26,89 \%$ jika dibandingkan terhadap nilai MOR balok kayu Meranti dan meningkat $36,9 \%$ jika dibandingkan terhadap nilai MOR BL LM. Artinya penambahan paku sebagai bahan perekat pada balok laminasi yang menggunakan lem, dapat meningkatkan nilai MOR dari balok laminasi itu sendiri.

Balok laminasi yang menggunakan 2 bahan perekat lem+baut (BL LB), mempunyai nilai MOR sebesar $18,37 \mathrm{Mpa}$, nilai ini lebih kecil $29,18 \%$ jika dibandingkan terhadap nilai MOR balok kayu Mahang, lebih kecil 53,53\% jika dibandingkan terhadap nilai MOR balok kayu Meranti dan lebih kecil 49,86\% jika dibandingkan terhadap nilai MOR BL LM. Artinya penambahan baut pada balok laminasi yang menggunakan lem, dapat menurunkan nilai MOR dari balok laminasi itu sendiri.

Hal ini mungkin dipengaruhi oleh luas penampang yang tereduksi akibat penggunaan baut pada daerah tarik balok atau bagian bawah ditengah bentang balok. Sehingga balok tidak mampu memikul beban walaupun sudah menggunakan dua bahan perekat. Berbeda dengan penggunaan lem + paku sekaligus (BL LP), penggunaan bahan perekat paku tidak menyebabkan terjadinya pengurangan luas penampang di bagian tarik yang signifikan seperti menggunakan baut, sehingga balok masih mampu 
memikul beban jika dibandingkan balok laminasi lem+baut (BL LB).

Penentuan nilai modulus elastisitas balok laminasi dilakukan dengan menggunakan Pers. 2. Dari hasil perhitungan diperoleh nilai MOE seperti pada Gambar 13 berikut ini.

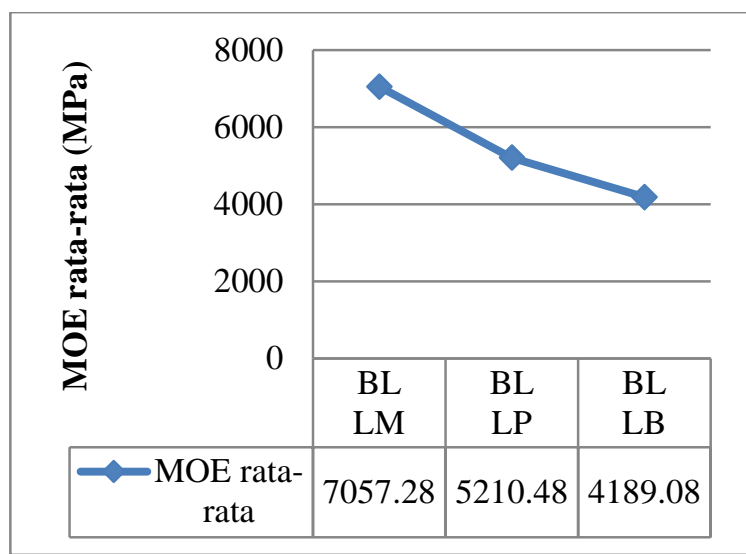

Gambar 13. Grafik nilai MOE balok laminasi

Pada Gambar 10 diketahui bahwa balok laminasi lem (BL LM) punya nilai MOE yang lebih besar dibanding dengan balok laminasi lainnya yaitu sebesar 7057,28 Mpa. Sementara untuk balok laminasi yang menggunakan dua bahan perekat BL LP mempunyai nilai MOE sebesar 5210,48 Mpa atau lebih kecil 26,16\% jika dibandingkan dengan BL LM. Untuk BL LB mempunyai nilai MOE sebesar 4189,08 Mpa atau lebih kecil 40,06\% jika dibandingkan dengan BL LM. hal ini menunjukkan bahwa, penambahan paku dan baut pada balok laminasi yang menggunakan perekat lem dapat menurunkan nilai MOE dari balok laminasi itu sendiri.

Jika dilihat dari pola keruntuhan pada saat pengujian balok lentur, keruntuhan balok BL LM ditandai dengan retak awal pada layer paling bawah di tengah bentang, seiring dengan bertambahnya beban maka layer bawah mengalami patah, kemudian diikuti dengan terlepasnya layer bagian bawah dan pada saat inilah beban maksimum tercapai seperti yang terlihat pada Gambar 14.

Balok laminasi BL LP keruntuhan diawali di bagian bawah ditengah bentang (daerah tarik) yang kemudian seiring dengan bertambahnya beban maka retak menjalar ke bagian atas balok. Seperti yang terlihat pada Gambar 15.

Balok laminasi yang menggunakan perekat lem + baut (BL LB) retak pertama diawali dari lubang baut bagian bawah balok di tengah bentang. Seiring dengan pertambahan beban retak menjalar dan menyebabkan patahnya layer bagian bawah. Hal ini menunjukkan bahwa penempatan alat sambung (baut) ditengah bentang tidak memadai atau dapat menurunkan kapasitas lentur dari balok laminasi.

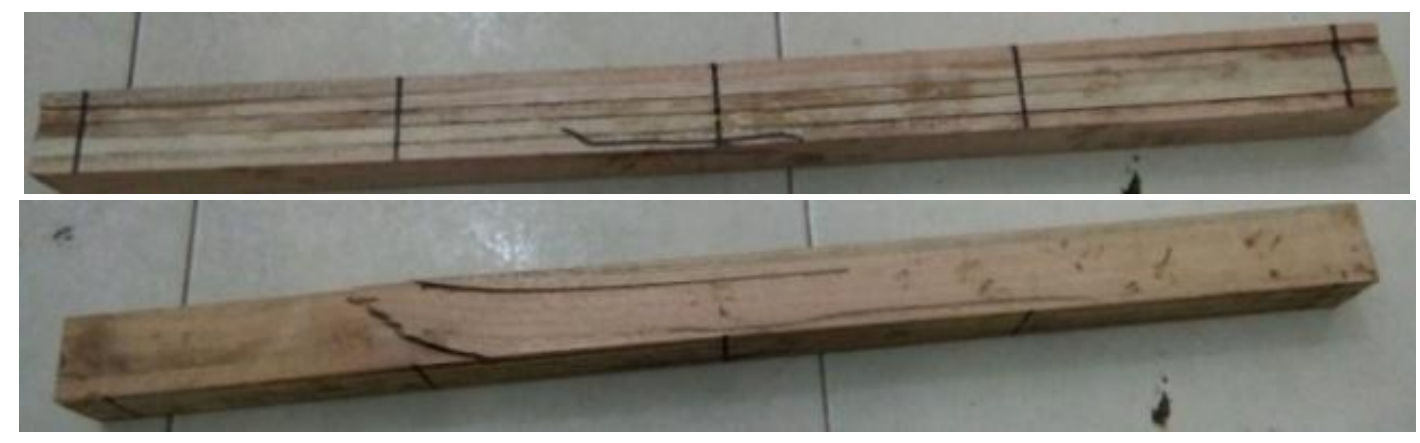

Gambar 14. Pola keruntuhan balok laminasi dengan perekat lem (BL LM) 


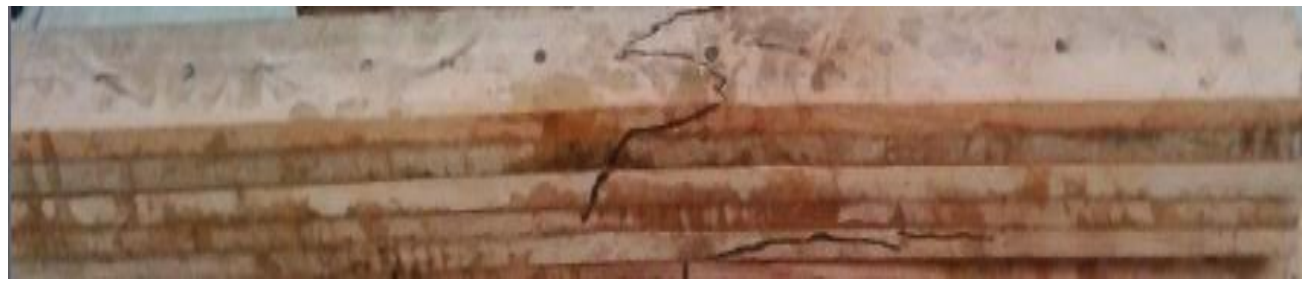

Gambar 15. Pola keruntuhan balok laminasi dengan perekat lem + paku (BL LP)

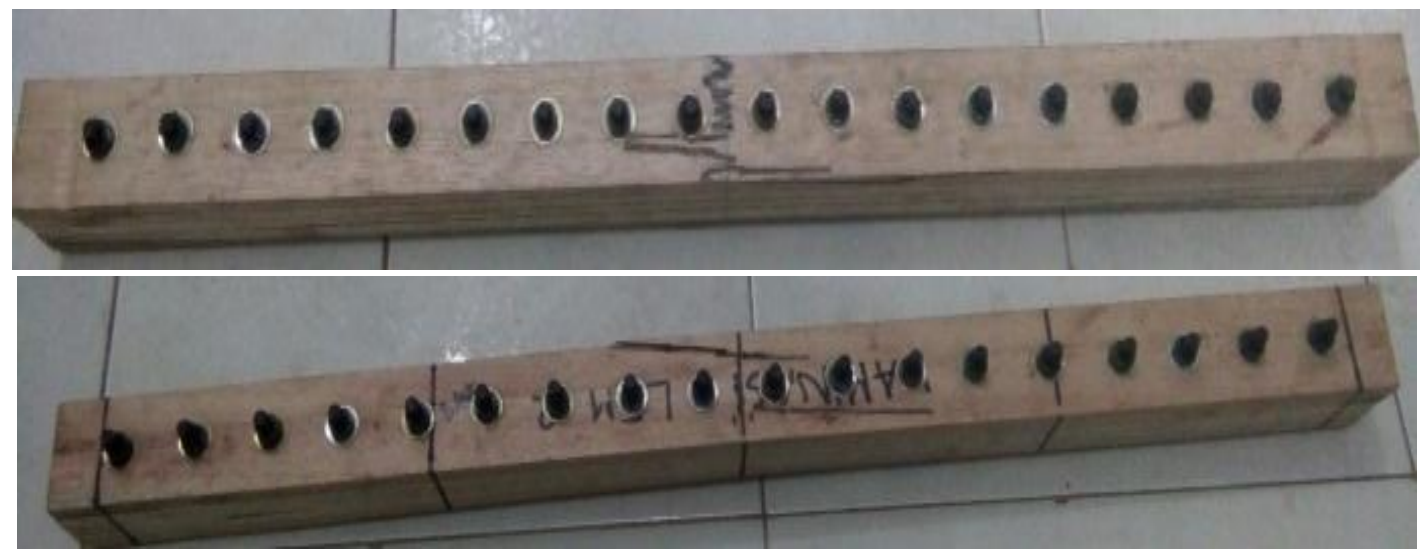

Gambar 16. Pola keruntuhan balok laminasi dengan perekat lem + baut (BL LB)

\section{SIMPULAN}

Berdasarkan hasil Kajian dan pembahasan dapat ditarik kesimpulan sebagai berikut: 1) Penambahan paku sebagai bahan perekat pada balok laminasi (BL LP) dapat meningkatkan nilai MOR sebesar $36,9 \%$, dan penambahan baut sebagai bahan perekat balok laminasi (BL LB) dapat menurunkan nilai MOR balok laminasi sebesar 49,86\%; 2) Penambahan paku dan baut pada balok laminasi yang menggunakan perekat lem dapat menurunkan nilai MOE dari balok laminasi itu sendiri masing-masing sebesar 26,16\% dan $40,06 \%$.

\section{DAFTAR RUJUKAN}

Awaludin Ali. 2011. Kajian sifat-sifat fisika dan mekanika kayu Glugu dan Sengon kawasan Merapi dalam rangka mempercepat pemulihan ekonomi masyarakat Merapi pasca letusan Merapi 2010. Diakses tanggal 10 Maret 2016, awaludin.staff.ugm.ac.id/files/2011/03

Budi Agus Setiya. 2007. Pengaruh Dimensi Bilah Terhadap Keruntuhan Lentur Balok Laminasi Bambu Peting. Media Teknik Sipil. hal 85-91.

Badan Standarisasi Nasional. 2013. Standar Nasional Indonesia (SNI 7939-2013) Spesifikasi desain untuk konstruksi kayu.

Badan Standarisasi Nasional. 1995. Standar Nasional Indonesia (SNI 033959-1995) Metode pengujian kuat lentur kayu di laboraturium.

Dumanauw, J.F.(1984). Mengenal Kayu. Edisi 2 Cetakan 2. Jakarta:T. Gramedia 
Pengaruh Penambahan Baut ... (Indriyani/ hal. 62-74)

lensufrie, Tikno. (2009). Mengenal Teknik Pengeringan Kayu. Surabaya: Erlang

Jihannanda Pramudito. (2013). Studi Kuat Lentur Balok Laminasi Kayu Sengon Dengan Kayu Kelapa Di Daerah
Gunung Pati Semarang. Semarang: Universitas Negeri Semarang.

Prihadi, W. R., \& Pratama, G. N. I. P. Konfigurasi Batang Pada Perancangan Rangka Atap Bambu. INERSIA, 12(2), 173-183. 